\title{
Paramyxo- and Coronaviruses in Rwandan Bats
}

\author{
Wanda Markotter ${ }^{1, *} \mathbb{0}$, Marike Geldenhuys ${ }^{1}$, Petrus Jansen van Vuren ${ }^{1,2} \mathbb{C}$, Alan Kemp ${ }^{2} \mathbb{C}$, \\ Marinda Mortlock ${ }^{1}$ (D), Antoine Mudakikwa ${ }^{3}$, Louis Nel ${ }^{4}$, Julius Nziza ${ }^{5}$, Janusz Paweska ${ }^{1,2}{ }^{\mathbb{D}}$ \\ and Jacqueline Weyer ${ }^{1,2}$ (D) \\ 1 Centre for Viral Zoonoses, Department of Medical Virology, Faculty of Health Sciences, University of \\ Pretoria, Pretoria, Gauteng 0001, South Africa \\ 2 Centre for Emerging Zoonotic and Parasitic diseases, National Institute for Communicable Diseases, \\ National Health laboratory Services, Sandringham, Johannesburg 2131, South Africa \\ 3 Rwanda Development Board, Department of tourism and Conservation, P.O Box 6239, Kigali, Rwanda \\ 4 Centre for Viral Zoonoses, Department of Biochemistry, Genetics and Microbiology, Faculty of Natural and \\ Agricultural Sciences, University of Pretoria, Pretoria, Gauteng 0001, South Africa \\ 5 Mountain Gorilla Veterinary Project, P.O Box 115, Musanze, Rwanda \\ * Correspondence: wanda.markotter@up.ac.za; Tel.: +27-319-2353
}

Received: 31 May 2019; Accepted: 21 June 2019; Published: 2 July 2019

\begin{abstract}
A high diversity of corona- and paramyxoviruses have been detected in different bat species at study sites worldwide, including Africa, however no biosurveillance studies from Rwanda have been reported. In this study, samples from bats collected from caves in Ruhengeri, Rwanda, were tested for the presence of corona- and paramyxoviral RNA using reverse transcription PCR assays. Positive results were further characterized by DNA sequencing and phylogenetic analysis. In addition to morphological identification of bat species, we also did molecular confirmation of species identities, contributing to the known genetic database available for African bat species. We detected a novel Betacoronavirus in two Geoffroy's horseshoe bats (Rhinolophus clivosus) bats. We also detected several different paramyxoviral species from various insectivorous bats. One of these viral species was found to be homologous to the genomes of viruses belonging to the Jeilongvirus genus. Additionally, a Henipavirus-related sequence was detected in an Egyptian rousette fruit bat (Rousettus aegyptiacus). These results expand on the known diversity of corona- and paramyxoviruses and their geographical distribution in Africa.
\end{abstract}

Keywords: paramyxovirus; coronavirus; Rwanda; bat; surveillance; caves; barcoding; henipavirus; jeilongvirus

\section{Introduction}

Bats (Order Chiroptera) account for $20 \%$ of all mammalian species and are distributed worldwide. With the advancement in detection techniques and increased surveillance, bats are being increasingly recognized as hosts for many zoonotic viruses [1], including filo-, paramyxo-, corona- and lyssaviruses [2-5]. Regions in Africa are considered a hotspot for emerging infectious diseases with more than $50 \%$ of recently emerging diseases originating from wildlife species on this continent $[6,7]$. Although several surveillance studies have been implemented to detect potential zoonotic viruses in bats, including from countries in the Congo basin and East Africa, limited information is available for Rwanda. Importantly, in the bordering Democratic Republic of Congo and Uganda, Marburg and Ebola disease outbreaks in humans have occurred [8], and corona- and paramyxoviruses have been reported to circulate in bats [3,9-11]. 
Coronaviruses are positive-sense RNA viruses with the potential to cause respiratory, gastrointestinal, hepatic, and neurological diseases in their hosts [12] and are divided into four genera namely Alphacoronavirus, Betacoronavirus, Gammacoronavirus, and Deltacoronavirus [5]. Bats host a large diversity of coronaviruses and the expanding research can be largely attributed to the emergence of novel coronaviruses of public health and veterinary importance. Three such viruses emerged in the last 17 years, including the severe acute respiratory syndrome (SARS) coronavirus in 2002, Middle East respiratory syndrome (MERS) coronavirus in 2012, and the swine acute diarrhoea syndrome (SADS) coronavirus in 2017 [13,14].

Bat coronaviruses have been shown to be associated with particular bat genera and similar viruses have been identified throughout the geographical distribution of their hosts [11,12,15]. Diverse bat coronaviruses related to SARS coronavirus (now termed the Sarbecovirus subgenus) have been identified from the Rhinolophus bat genus (Horseshoe bats) in Asia, Europe and Africa [11,16,17]. Continued surveillance within these bats species in China identified lineages of recombinant SARS-related coronaviruses nearly identical to human SARS coronaviruses, capable of using the same receptor molecules [17-19]. As a result, these viruses have therefore been postulated to be capable of direct human infection $[18,19]$. Bats from various African countries, including Kenya, Ghana, Nigeria, Tanzania, Uganda and South Africa, have yielded a large diversity of novel coronaviruses [11,20-27]. Some of the bat coronaviruses identified have been shown to be genetically related to known human coronaviruses such as HCoV-229E, HCoV-NL63, and MERS coronavirus [11,21,24-26].

Paramyxoviruses are negative-sense single-stranded RNA viruses capable of infecting a diverse host range including mammals, birds, reptiles and fishes [28]. The taxonomic classification of viruses in the Paramyxoviridae family has recently undergone several changes [29]. In an attempt to accommodate the rapidly growing number of paramyxoviruses described, the previously known Avulavirus and Rubulavirus genera were elevated to the sub-family level (Avula- and Rubulavirinae) each with two new genera. In addition, several unclassified rodent-borne viruses were classified to newly established genera (Narmovirus and Jeilongvirus) in the sub-family Orthoparamyxovirinae to which the Henipa-, Morbilli- and Respirovirus genera belong.

Several zoonotic paramyxoviruses have emerged as important public health threats in the past three decades. The emergence of Hendra and Nipah viruses (Henipavirus genus) during the 1990s in Australia and Southeast Asia respectively, marked the first report of zoonotic paramyxoviruses of considerable public health importance [30,31]. These viruses are characterized by high morbidity and mortality rates and outbreaks have been reported on a near annual basis. In addition, another paramyxovirus, Sosuga virus (Pararubulavirus genus), emerged as the etiological agent of a single non-fatal human infection contracted in Uganda, Africa [32]. The natural wildlife reservoir for these zoonotic viruses was determined to be the fruit bat species occurring in these areas, i.e., flying foxes from the Pteropus genus for the henipaviruses [33,34], and the Egyptian rousette bat (Rousettus aegyptiacus) for the rubulavirus [9]. Viruses related to the Henipa- and Orthorubula- and Pararubulavirus genera as well as a number of unclassified viruses have been described from countries bordering Rwanda as well as other African countries [3,9,10,35-37]. R. aegyptiacus, Hipposideros spp. and Miniopterus inflatus have tested positive for paramyxoviral RNA that is closely related to known human pathogens including the henipaviruses, human mumps virus, human parainfluenza virus 2 and human parainfluenza virus $4[3,37]$.

In this study, we report the detection of a novel Betacoronavirus in Rhinolophus clivosus sampled in the Ruhengeri cave system in Rwanda. In addition, we report on the detection of Jeilongvirus and related sequences in Hipposideros spp. as well as a Henipavirus-related sequence in the fruit bat species R. aegyptiacus. These results expand on the known diversity of these virus groups and their geographical distribution in Africa. 


\section{Materials and Methods:}

\subsection{Study Area and Sample Collection}

In December 2008, a team from the University of Pretoria, National Institute for Communicable Diseases, and Rwanda Tourism Board and National Park Authority visited two cave sites in Ruhengeri, Rwanda (GPS coordinates: 130'14.2” S 29³7'59.9” E; Figure 1) where bats were caught at night using mist nets in the surrounding areas, and two bank G4 Forest Strainer harp traps (Bat Conservation and Management, Inc., USA, Australia) at the cave entrances. When collecting samples in the field, personal protective equipment used included Tyvek suits (DuPont ${ }^{\mathrm{TM}}$, Wilmington, DE, USA), disposable over gowns (Stylianou MediSupplies 1td, Middle East), 3M full powered air purifying respirators (3M, Maplewood, MN, USA), gumboots (Bata Industries ${ }^{\circledR}$, Pinetown, South Africa), double layer nitrile gloves (Lasec, Cape Town, South Africa) and leather gloves (Evrigard, Johannesburg, South Africa).

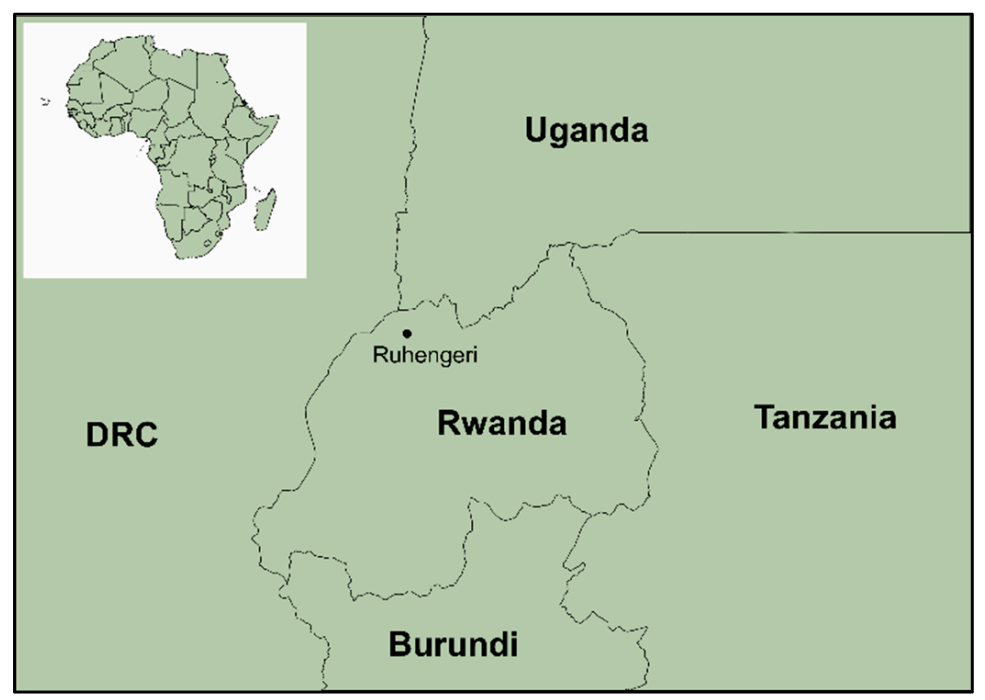

Figure 1. A map of Rwanda and bordering countries. The black dot indicates the site of the two caves in Ruhengeri where sampling was conducted. Map generated using the QGis software.

Bats were placed in individual cotton bags before processing. Bats were morphologically identified [38] and data including sex, reproductive status, forearm length and weight were also recorded. Samples collected from bats included fecal and oral swabs, wing biopsies in $70 \%$ ethanol and blood (serum) for use in viral surveillance studies. Oral swabs were collected by gently swabbing the inside of the mouth (cheeks and tongue) with a sterile swab (VWR Critical Swab, Atlanta, GA, USA). Fecal material or swabs (VWR Critical Swab, Atlanta, GA, USA) were collected from the bat or the cotton bag, when it was available. Sterile foreceps were used to collect fecal pellet(s) and place them in $2 \mathrm{~mL}$ microcentrifuge tubes (Sarstedt, Nümbrecht, Germany). Urine was collected with a sterile swab (VWR Critical Swab, Atlanta, GA, USA) from individual bats as was available. In instances where bats died during processing, necropsies were performed and various organs and tissues, including kidney, spleen, heart, pectoral muscles, liver, lung, stomach, bladder, tongue, brain and lymph nodes, were collected and placed in $2 \mathrm{~mL}$ cryotubes (Sarstedt, Nümbrecht, Germany). All samples were collected in RNALater preservative inactivation solution (Qiagen, Hilden, Germany), stored at $4{ }^{\circ} \mathrm{C}$, then transported to and tested in South Africa at the National Institute for Communicable Diseases (NICD) and University of Pretoria. Permits were obtained from the Rwanda Development Board/Tourism \& Conservation and animal ethics was obtained from the Animal Ethics Committee, University of Pretoria. 


\subsection{RNA and DNA Extraction}

For viral RNA detection, RNA was extracted from kidney, spleen, urine, fecal, rectal and intestinal samples (Table S1). RNA from kidney $(n=6)$, spleen $(n=5)$ and urine $(n=13)$, were extracted using the TRIzol reagent (Invitrogen, Carlsbad, CA, USA), and fecal material/swabs $(n=99)$, rectal and/or intestinal samples $(n=8)$ (Table S1) were extracted using the Duet RNA/DNA extraction kit (Zymoresearch, CA, USA) from samples homogenized in $300 \mu \mathrm{L}$ of phosphate buffered saline (Lonza, Basel, Switzerland). Both extraction methods were performed according to the manufacturer's instructions without deviations.

\subsection{Morphological and Molecular Host Species Identification}

DNA was extracted using the DNeasy Blood \& Tissue Kit (Qiagen, Hilden, Germany) from heart tissues. Confirmation of species identification of bats, in which viral RNA was detected, was performed by amplifying the cytochrome $\mathrm{b}(\mathrm{cyt} b$ ) or cytochrome oxidase one (COI) gene region and determining the DNA sequence. Selection of cytochrome region for amplification was based on availability of credible comparative sequences in public databases (NCBI Genbank and BOLD). Previously reported PCR primers targeting these two regions were used or modified [39-41]. For the cyt $b$ gene amplification, $1 \times$ DreamTaq buffer ${ }^{\mathrm{TM}}(10 \times$, ThermoFisher Scientific, Waltham, MA, USA), $2 \mu \mathrm{L}$ Cyt $b$-forward modified primer ( $10 \mathrm{mM}$, Integrated DNA technologies, Coralville, IA, USA) (5'-CGA AGC TTG ATA TGA AAA ACC ATC GTT-3'), $2 \mu \mathrm{L}$ Cyt $b$-reverse modified primer (5'-TGT AGT TRT CWG GGT CHT CTA-3') (10 mM, Integrated DNA Technologies, USA), $1 \mu \mathrm{L}$ dNTPs mix (10 $\mathrm{mM}$, Invitrogen, Carlsbad, CA, USA), $0.25 \mu \mathrm{L}$ of DreamTaq polymerase $(5 \mathrm{U} / \mu \mathrm{L}$, Thermo Scientific, USA), and nuclease-free water (Ambion, Foster City, CA, USA) to a final volume of $45 \mu \mathrm{L}$ was prepared. A volume of $5 \mu \mathrm{L}$ of extracted DNA was added to the reaction and incubated in a SimpliAmp automated thermal cycler (Thermofisher Scientific, Waltham, MA, USA) at $94{ }^{\circ} \mathrm{C}$ for $2 \mathrm{~min} ; 45$ cycles of $94{ }^{\circ} \mathrm{C}$ for $30 \mathrm{~s}, 50{ }^{\circ} \mathrm{C}$ for $30 \mathrm{~s}$ and $72{ }^{\circ} \mathrm{C}$ for $90 \mathrm{~s}$; and $72{ }^{\circ} \mathrm{C}$ for $10 \mathrm{~min}$. Amplification of the partial COI gene was done using the Folmer-LCO1490 forward (5'-GGT CAA CAA ATC ATA AAG ATA TTG G-3') and Folmer-HCO2198 reverse (5'-TAA ACT TCA GGG TGA CCA AAA AAT CA-3') primers as described for the cyt $b$ gene with an annealing temperature of $48^{\circ} \mathrm{C}$.

Following the PCR analysis, reactions were subjected to agarose gel electrophoresis on a $1.5 \%$ agarose gel (Lonza, Basel, Switzerland) and PCR amplicons were gel-purified using the Wizard ${ }^{\circledR} \mathrm{SV}$ Gel DNA clean-up system (Promega, Madison, WI, USA) according to the manufacturer's instructions and without deviation. All amplicons were subjected to Sanger sequencing for both the forward and reverse reactions on an ABI 3100 DNA sequencer (AE Applied Biosystems) at the sequencing facility of the University of Pretoria. Host gene sequences were subsequently compared to bat sequences available in the public domain (on the NCBI GenBank and BOLD databases), results were interpreted and compared with the respective morphological field identifications.

\subsection{PCR Amplification of Viral Targets}

\subsubsection{Coronaviruses}

Fecal, rectal and/or intestinal samples from 101 bats (Table S1) were extracted and analysed for coronavirus RNA. Complementary DNA (cDNA) was prepared using $100 \mathrm{ng}$ random hexamers (IE HPLC Purified, Integrated DNA Technologies, Coralville, IA, USA) with 200 U Superscript IV Reverse transcriptase (Thermo Scientific, Waltham, MA, USA). Additionally, cDNA was treated with $2 \mathrm{U}$ RNase H (Thermo Fisher Scientific) incubation at $37^{\circ} \mathrm{C}$ for $20 \mathrm{~min}$ and inactivated at $65^{\circ} \mathrm{C}$ for $10 \mathrm{~min}$. Presence of coronavirus RNA was detected with a coronavirus genus-specific hemi-nested RT-PCR assay which targets the RNA dependent RNA polymerase (RdRp) gene for amplification as described in Geldenhuys et al. [27]. As the hemi-nested RT-PCR assay produced only short amplicons (approximately $260 \mathrm{bp}$ ), the RdRp-grouping unit (RGU) assay was used to extend the sequenced region of the identified betacoronaviruses to $820 \mathrm{bp}$ [16]. A hemi-nested RT-PCR assay was performed using 
the randomly primed cDNA prepared as well as forward primers from Drexler et al. [16] (SP3080 5'-CTT CTT CTT TGC TCA GGA TGG CAA TGC TGC-3' and SP3195 5'-ATA CTT TGA TTG TTA CGA TGGT GGC TG-3') in combination with a reverse primer (P1Beta_Rev2016 5'-CAT CRT CAS DIA RDA TCA TCAT-'3) from the Geldenhuys et al. [27] assay. Assay conditions from Geldenhuys et al. [27] were used with modifications to cycling conditions including longer annealing and extension cycles ( 45 cycles of $94^{\circ} \mathrm{C}$ for $30 \mathrm{~s}, 42^{\circ} \mathrm{C}$ for $60 \mathrm{~s}$ and $72{ }^{\circ} \mathrm{C}$ for $80 \mathrm{~s}$ ). Agarose gel electrophoresis and purification of all PCR products were performed as previously described for molecular host species identification.

\subsubsection{Paramyxoviruses}

Kidney from insectivorous bats, spleen from frugivorous bats and urine from both groups $(n=24$; Table S1) were tested with the use of two broadly-reactive assays targeting the Avula-Rubulavirinae (AR) sub-families, and the Respiro-Morbilli-Henipvirus (RMH) genera. For both assays, published primers targeting the conserved polymerase (L) gene [42] were used in combination with adapted two-step hemi-nested RT-PCR protocols. Samples were tested with the AR assay as previously described [37]. For the RMH assay, the samples were tested as previously described [37], with minor variations in the protocol. For the first-round PCR, $25 \mathrm{mM} \mathrm{MgCl}_{2}$ (ThermoFisher Scientific, Waltham, MA, USA) was added and the nuclease-free water (Ambion, Foster City, CA, USA) was adapted for a final reaction volume of $50 \mu \mathrm{L}$. All cycling conditions and the protocol for the hemi-nested PCR remained the same as for AR. Agarose gel electrophoresis and purification of all PCR products were performed as previously described for molecular host species identification.

\subsection{Sequencing and Phylogenetic Analysis}

Sequencing was performed as previously described for molecular host species identification. Sequences were viewed, edited and a consensus generated using the BioEdit sequence alignment editor software version 7.2.5 [43]. CIPRES was used for ClustalX alignments, determining the best DNA substitution model for nucleotide sequence analysis using the jModelTest software and for constructing Bayesian phylogenies using the BEAST version 1.8 software [44-46]. Bayesian MCMC chains were set to 20 million iterations, sampling every 2000 steps for optimal ESS scores. Output files were visually inspected to check for convergence using the Tracer software version 1.7 [47]. The final phylogenies were constructed in TreeAnnotator with a burn-in value of $10 \%$. For visualization and manipulation of the phylogenetic tree, the FigTree version 1.4.2 software was used. Pairwise similarities between sequences were analysed in MEGA X with complete deletion [48].

\section{Results and Discussion}

In total, samples from 101 bats constituting five genera were tested for coronaviruses (Table 1 and Table S1). Of these, two samples contained coronavirus RNA, originating from two individuals of the Rhinolophus genus. Barcoding and molecular identification confirmed the host species to be Rhinolophus clivosus (Table S1). Coronavirus sequences were extended to $820 \mathrm{bp}$ with RGU assay primer sets [16]. The two sequences ( $R h$-BtCoV/441/Rwanda/08 and $R h$ - BtCoV/445/Rwanda/08) share 99.9\% nucleotide identity; pairwise similarities and phylogenetic analysis group these sequences with other lineage B betacoronaviruses (Figure 2). The closest relative to the Rwandan betacoronavirus was reported from Kenya, BtCoVKY72 (Tao et al. unpublished; Genbank accession number KY352407.1), though the Rhinolophus species is not specified. The sequences share very close sequence similarities $(95.5 \%$ nucleotide identity and $100 \%$ amino acid identity), suggesting that similar betacoronaviruses may be harbored by both Kenyan and Rwandan Rhinolophus bats. Full genome comparisons will be able to determine if Kenyan and Rwandan Rhinolophus bats are infected by the same betacoronavirus species. Within the analyzed conserved RdRp gene segment, this Rwandan Rhinolophus betacoronavirus also shares pairwise similarities of $88 \%$ nucleotide identity (98.9\% amino acid identity) to the Bulgarian betacoronavirus $R h$-BtCoV/BM48-31/BGR/08 [16], as well as close similarities (86.1-86.4\% nucleic acid similarity and 98.9-99.2\% amino acid identity) to Asian Rhinolophus SARS-related coronaviruses such as 
SARSr-Rh-BtCoV/Rp3 and SARSr-Rh-BtCoVWIV16 [18,49]. Other coronavirus surveillance in Rwanda, and surrounding countries such as Uganda and Tanzania also report SARS-related coronaviruses from the Rhinolophus genus [11]. Unfortunately, the sequences cannot be compared as an assay targeting a different conserved peptide of the RdRp gene was used [22].

Table 1. Bat-associated paramyxo- and coronavirus RNA detected from bats in the Ruhengeri caves in Rwanda.

\begin{tabular}{lccc}
\hline \multicolumn{1}{c}{ Bat Species } & $\begin{array}{c}\text { Paramyxovirus } \\
\text { Positive/Total }\end{array}$ & $\begin{array}{c}\text { Coronavirus } \\
\text { Positive/Total }\end{array}$ & Ruhengeri Site \\
\hline $\begin{array}{l}\text { Hipposideros ruber } \\
\text { (Noack's roundleaf bat) }\end{array}$ & $\mathbf{2 / 3}$ & $0 / 2$ & Cave 1 \\
\hline $\begin{array}{l}\text { Otomops martiensseni } \\
\text { (Large eared free-tailed bat) }\end{array}$ & $\mathbf{1 / 4}$ & $0 / 15$ & Cave 1 \\
\hline $\begin{array}{l}\text { Rousettus aegyptiacus } \\
\text { (Egyptian Rousette fruit bat) }\end{array}$ & $\mathbf{1 / 1 4}$ & $0 / 72$ & Cave 1 \\
\hline $\begin{array}{l}\text { Rhinolophus spp. } \\
\text { (Horseshoe bat) }\end{array}$ & $0 / 2$ & $2 / 7$ & Cave 2 \\
\hline $\begin{array}{l}\text { Epomophorus spp. } \\
\text { (Epauletted fruit bat) }\end{array}$ & - & $0 / 5$ & Cave 1 \\
\hline Total & $4 / 23$ & $\mathbf{2} \mathbf{1 0 1}$ & \\
\hline
\end{tabular}

Boldface indicates positive samples.

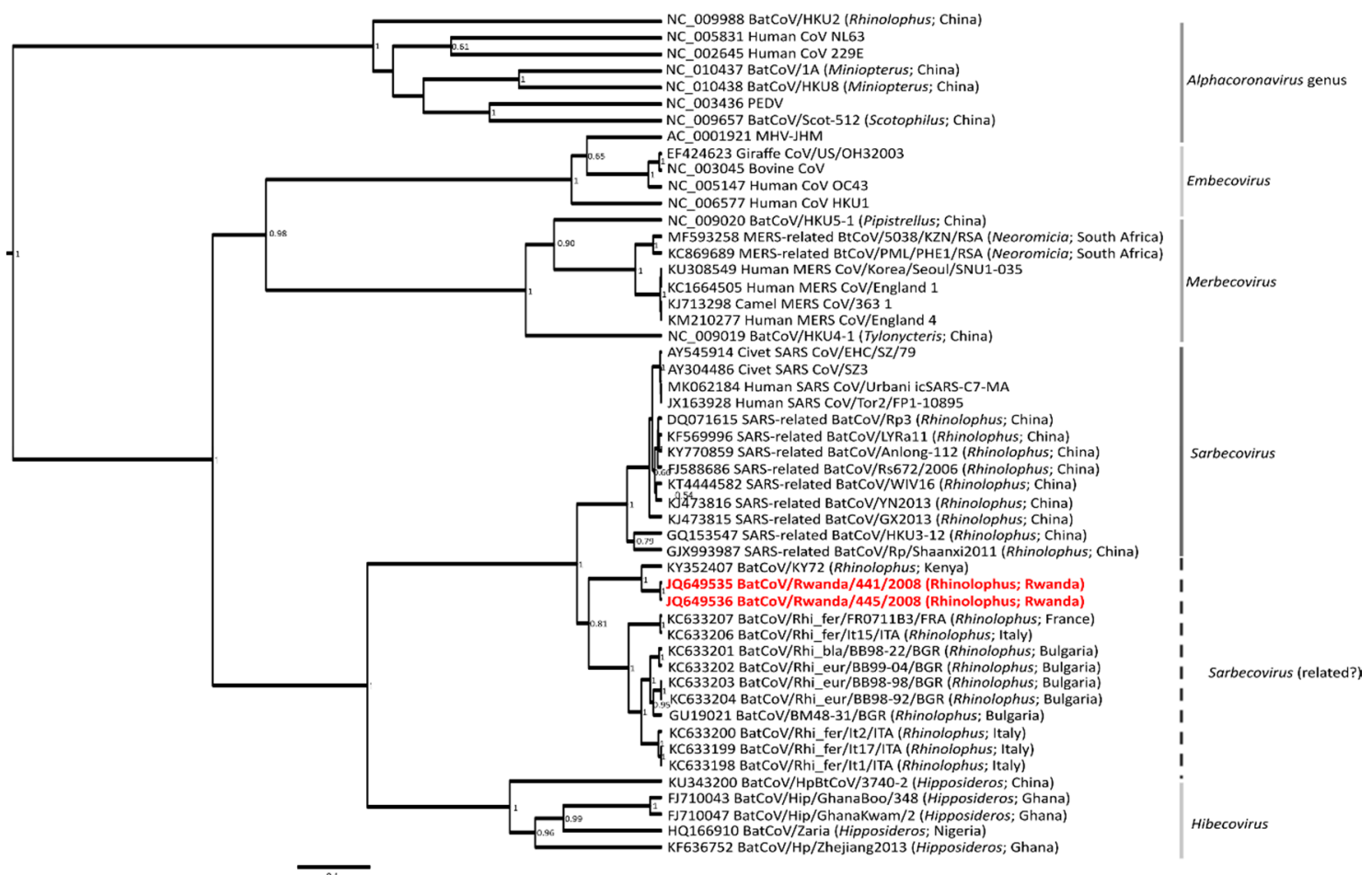

Figure 2. Bayesian phylogeny constructed based on a trimmed $780 \mathrm{bp}$ sequence region of the $\mathrm{RdRp}$ gene of the coronavirus genome. The general time reversible model using gamma and invariant sites was determined using the jModelTest software version 2.1.6. The phylogeny was constructed using the BEAST version 1.8. Posterior probabilities of $>0.5$ are indicated at internal nodes. Subgenus and genus designations are indicated on the right, and sequences from this study are in red. 
Twenty-four samples from 23 bats were tested for paramyxovirus RNA (Table S1), none of which tested positive with the Avula-Rubulavirinae (AR) assay. An overall percentage positivity for paramyxovirus RNA, detected using the Respiro-Morbilli-Henipavirus (RMH) assay, was found to be $16.6 \%(n=4)$. Three of the viral sequences were detected in the insectivorous bat species Hipposideros ruber and Otomops martiensseni, while one other sequence was detected in the frugivorous bat species Rousettus aegyptiacus. Host identification of positive samples was confirmed using molecular analysis (Table S1). Phylogenetic analysis of the sequences indicated that the insectivorous bat-borne viral sequences grouped with the Jeilongvirus genus as well as in a Jeilongvirus-related clade (Figure 3). One of the H. ruber sequences (BatPV/Hip_rub/UP401/RWA/2008) described from this study potentially groups within the Jeilongvirus genus. The second H. ruber-derived viral sequence (BatPV/Hip_rub/UP450/RWA/2008) grouped with a paramyxoviral sequence detected in a bat from the same genus sampled in Cameroon in 2010, however, was not identical. The detection of two diverse viruses from bats of the same species and same population has previously also been reported in insectivorous bats sampled in other African countries [36]. These observations can in part be explained by the generation of viral quasi-species populations due to the high mutation rate of RNA viruses as a consequence of RNA proofreading deficiency of the RNA dependent RNA polymerase [50]. A larger pool of diverse viruses within a bat population and the co-roosting of several cave-dwelling bat species may facilitate viral sharing between different bat species [51]. However, ongoing biosurveillance in these cave-dwelling bat species will be required before active viral sharing can be shown. The paramyxoviral sequence detected in the O. martiensseni bat (BatPV/Oto_mar/UP535/RWA/2008) was near identical to the viral sequences previously described from several individuals of the same species sampled in Kenya in 2011 [36]. These sequences shared a 99.3\% similarity on both nucleotide and amino acid level. The R. aegyptiacus-derived viral sequence (BatPV/Rou_aeg/UP438/RWA/2008) grouped within a Henipavirus-related clade and was near identical to a paramyxoviral sequence detected in the same host species previously reported from Kenya [36]. Sequence similarity shared between these two sequences was found to be $98.1 \%$ and $98.7 \%$ on nucleotide and amino acid level, respectively.

To our knowledge, this study reports on the first evidence of paramyxovirus RNA in bats from Rwanda. Two of the four viral sequences detected in $H$. ruber, were not closely related to the paramyxovirus sequences previously reported (sharing nucleotide and amino acid similarities of less than $80 \%$ and $83.5 \%$, respectively) and might represent novel viral species. However, a more rigorous analysis with variable genes such as the fusion and hemagglutinin gene will be required before putative species can be inferred. As observed in previous studies, viral sequences from frugivorous bats were mostly found to belong to the Henipavirus genus or a related clade, while insectivorous bat-associated viral sequences have been linked to other genera including Morbilli- and Jeilongvirus [36]. This observation was again reflected in the current study.

The detection of highly similar viral sequences from bats in Rwanda and Kenya, which are more than $1000 \mathrm{~km}$ apart, can be explained by either the phenomena of metapopulations or the hypothesis of co-evolution of paramyxoviruses with their bat hosts [3,52,53]. RNA viruses have an exceptionally high mutation rate commonly associated with quasi-species populations and with the potential to cross the species barrier, among others. This is evident in the high diversity of paramyxoviruses described to date and the wide host range associated with these viruses $[3,28,36,54]$. Additionally, due to the emergence of SARS, MERS and SADS, it is widely accepted that coronaviruses are capable of readily adapting to new hosts [5]. The Rwandan caves are considered an ecotourism site and guano is also mined on a small scale, providing an ideal bat-human interface. Several insectivorous bat species co-roost with the Egyptian fruit bats in these caves and future studies should investigate viral sharing. The Egyptian fruit bat also uses these caves as a maternity roost and studies have shown that increased viral shedding is linked to reproductive cycles [37]. Longitudinal biosurveillance studies can therefore identify high risk periods in the future. As such, the detection of a SARS-related bat coronavirus potentially circulating within the Rhinolophus population and a Henipavirus-related paramyxovirus in R. aegyptiacus in the Ruhengeri region may merit further investigation to determine exposure, and the 
potential for spill-over events to occur. To date, emphasis of paramyxovirus surveillance has mostly been placed on fruit bats, the Henipavirus genus and related viruses due to the association of other henipavirus species with zoonotic events [30,31]. However, research regarding the zoonotic potential of the insectivorous bat-associated viruses is still lacking. One major aim regarding surveillance of wildlife populations is to identify potential zoonotic agents and to evaluate any threat to the public as well as domestic animal health. Though these bat-borne viruses are unlikely to pose a significant threat, it still merits continued monitoring of the chiropteran species within these caves as well as mammalian species that inhabit the surrounding area.

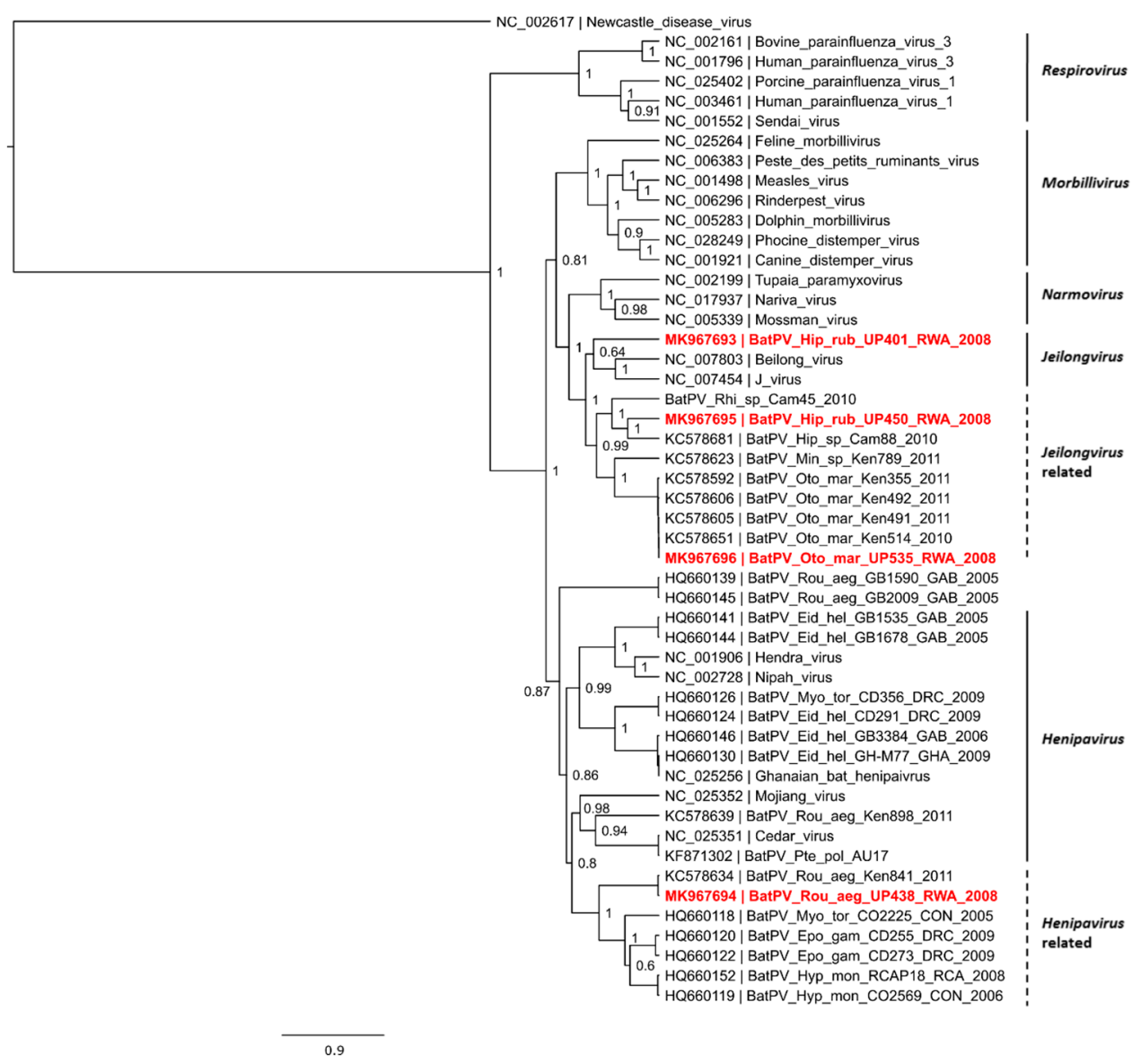

Figure 3. Phylogeny of the 439 nucleotide length sequences of the polymerase (L) gene of paramyxoviruses detected in bats from Rwanda using Respiro-Morbilli-Henipavirus genus-specific primers. Bayesian phylogenetic analysis was performed using the general time reversible model using the gamma and invariant site substitution model. A proportional tree representation is provided. Newly detected sequences from this study are indicated in bold red. Newcastle disease virus was selected as the outgroup.

For countries where the bat-human interface is more pronounced, as a result of ecotourism, guano mining or bat hunting and consumption, surveillance is key to identify the diversity of viruses present and their potential host species. Longitudinal and well-structured surveillance programmes would better characterize the circulation and shedding periods of the paramyxo- and betacoronaviruses within the Ruhengeri cave system. Such information would be most valuable towards well-considered zoonotic disease risk assessments and mitigation strategies.

Supplementary Materials: The following are available online at http://www.mdpi.com/2414-6366/4/3/99/s1, Table S1: Bats collected and tested in this study. 
Author Contributions: Conceptualization, W.M., P.J.v.V., A.K., A.M., J.N., J.P. and J.W.; Data curation, W.M., M.G. and M.M.; Formal analysis, W.M., M.G., M.M. and J.W.; Funding acquisition, W.M., A.M. and J.P.; Investigation, W.M., M.G., P.J.v.V., A.K., M.M., A.M., L.N., J.N., J.P. and J.W.; Methodology, W.M., M.G., P.J.v.V., A.K., M.M., A.M. and J.W.; Project administration, W.M., A.M. and J.W.; Resources, W.M., A.M., L.N., J.N., J.P. and J.W.; Supervision, W.M. and J.W.; Writing—original draft, W.M., M.G. and M.M.; Writing—review and editing, W.M., M.G., P.J.v.V., A.K., M.M., A.M., L.N., J.N., J.P. and J.W..

Funding: This research was funded by the National Research Foundation (NRF), South Africaspecificallty the South African Research Chair initiative (held by Professor Wanda Markotter) of the Department of Science and Technology and National Research Foundation of South Africa (Grant No 98339).

Acknowledgments: We would also like to thank the staff of the Rwanda Tourism Board and National Parks and Wendy White from the KwaZulu-Natal Bat Interest Group for assisting in the logistics and fieldwork.

Conflicts of Interest: The authors declare no conflict of interest. The funders had no role in the design of the study; in the collection, analyses, or interpretation of data; in the writing of the manuscript, and in the decision to publish the results.

\section{References}

1. Olival, K.J.; Hosseini, P.R.; Zambrana-Torrelio, C.; Ross, N.; Bogich, T.L.; Daszak, P. Host and viral traits predict zoonotic spillover from mammals. Nature 2017, 546, 646-650. [CrossRef] [PubMed]

2. Olival, K.J.; Hayman, D.T.S. Filoviruses in bats: current knowledge and future directions. Viruses 2014, 6, 1759-1788. [CrossRef] [PubMed]

3. Drexler, J.F.; Corman, V.M.; Müller, M.A.; Maganga, G.D.; Vallo, P.; Binger, T.; Gloza-Rausch, F.; Rasche, A.; Yordanov, S.; Seebens, A.; et al. Bats host major mammalian paramyxoviruses. Nat. Commun. 2012, 3, 1-12. [CrossRef] [PubMed]

4. Markotter, W.; Coertse, J. Bat lyssaviruses. Rev. Sci. Tech. OIE 2018, 37, 385-400. [CrossRef] [PubMed]

5. Wong, A.C.P.; Li, X.; Lau, S.K.P.; Woo, P.C.Y. Global epidemiology of bat coronaviruses. Viruses 2019, $11,174$. [CrossRef] [PubMed]

6. Chan, E.H.; Brewer, T.F.; Madoff, L.C.; Pollack, M.P.; Sonricker, A.L.; Keller, M.; Freifeld, C.C.; Blench, M.; Mawudeku, A.; Brownstein, J.S. Global capacity for emerging infectious disease detection. Proc. Natl. Acad. Sci. USA 2010, 107, 21701-21706. [CrossRef] [PubMed]

7. Daszak, P.; Cunningham, A.A.; Hyatt, A.D. Emerging Infectious Diseases of Wildlife- Threats to Biodiversity and Human Health. Science 2000, 287, 443-449. [CrossRef]

8. Emperador, D.M.; Mazzola, L.T.; Wonderly Trainor, B.; Chua, A.; Kelly-Cirino, C. Diagnostics for filovirus detection: impact of recent outbreaks on the diagnostic landscape. BMJ Glob. Heal. 2019, 4, e001112. [CrossRef]

9. Amman, B.R.; Albarino, C.G.; Bird, B.H.; Nyakarahuka, L.; Sealy, T.K.; Balinandi, S.; Schuh, A.J.; Campbell, S.M.; Stroher, U.; Jones, M.E.B.; et al. A recently discovered pathogenic paramyxovirus, Sosuga virus, is present in Rousettus aegyptiacus fruit bats at multiple locations in Uganda. J. Wildl. Dis. 2015, 51, 774-779. [CrossRef]

10. Peel, A.J.; Sargan, D.R.; Baker, K.S.; Hayman, D.T.S.; Barr, J.A.; Crameri, G.; Suu-Ire, R.; Broder, C.C.; Lembo, T.; Wang, L.F.; et al. Continent-wide panmixia of an African fruit bat facilitates transmission of potentially zoonotic viruses. Nat. Commun. 2013, 4, 1-14. [CrossRef]

11. Anthony, S.J.; Johnson, C.K.; Greig, D.J.; Kramer, S.; Che, X.; Wells, H.; Hicks, A.L.; Joly, D.O.; Wolfe, N.D.; Daszak, P.; et al. Global patterns in coronavirus diversity. Virus Evol. 2017, 3, 1-15. [CrossRef] [PubMed]

12. Drexler, J.F.; Corman, V.M.; Drosten, C. Ecology, evolution and classification of bat coronaviruses in the aftermath of SARS. Antiviral Res. 2014, 101, 45-56. [CrossRef] [PubMed]

13. Zhou, P.; Fan, H.; Lan, T.; Yang, X.L.; Shi, W.F.; Zhang, W.; Zhu, Y.; Zhang, Y.W.; Xie, Q.M.; Mani, S.; et al. Fatal swine acute diarrhoea syndrome caused by an HKU2-related coronavirus of bat origin. Nature 2018, 556, 255-259. [CrossRef] [PubMed]

14. Cui, J.; Li, F.; Shi, Z.L. Origin and evolution of pathogenic coronaviruses. Nat. Rev. Microbiol. 2019, 17, 181-192. [CrossRef] [PubMed]

15. Leopardi, S.; Holmes, E.C.; Gastaldelli, M.; Tassoni, L.; Priori, P.; Scaravelli, D.; Zamperin, G.; De Benedictis, P. Interplay between co-divergence and cross-species transmission in the evolutionary history of bat coronaviruses. Infect. Genet. Evol. 2018, 58, 279-289. [CrossRef] [PubMed] 
16. Drexler, J.F.; Gloza-Rausch, F.; Glende, J.; Corman, V.M.; Muth, D.; Goettsche, M.; Seebens, A.; Niedrig, M.; Pfefferle, S.; Yordanov, S.; et al. Genomic characterization of severe acute respiratory syndrome-related coronavirus in European bats and classification of coronaviruses based on partial RNA-dependent RNA polymerase gene sequences. J. Virol. 2010, 84, 11336-11349. [CrossRef] [PubMed]

17. Hu, B.; Zeng, L.P.; Yang, X.L.; Ge, X.Y.; Zhang, W.; Li, B.; Xie, J.Z.; Shen, X.R.; Zhang, Y.Z.; Wang, N.; et al. Discovery of a rich gene pool of bat SARS-related coronaviruses provides new insights into the origin of SARS coronavirus. PLoS Pathog. 2017, 13,1-28. [CrossRef]

18. Ge, X.; Li, J.; Yang, X.; Chmura, A.A.; Zhu, G.; Epstein, J.H.; Mazet, J.K.; Hu, B.; Zhang, W.; Peng, C.; et al. Isolation and Characterization of a bat SARS-like coronavirus that uses the ACE2 receptor. Nature 2013, 503, 535-538. [CrossRef]

19. Yang, X.-L.; Hu, B.; Wang, B.; Wang, M.-N.; Zhang, Q.; Zhang, W.; Wu, L.-J.; Ge, X.-Y.; Zhang, Y.-Z.; Daszak, P.; et al. Isolation and characterization of a novel bat coronavirus closely related to the direct progenitor of Severe Acute Respiratory Syndrome coronavirus. J. Virol. 2016, 90, 3253-3256. [CrossRef]

20. Tong, S.; Conrardy, C.; Ruone, S.; Kuzmin, I.V.; Guo, X.; Tao, Y.; Niezgoda, M.; Haynes, L.; Agwanda, B.; Breiman, R.F.; et al. Detection of novel SARS-like and other coronaviruses in bats from Kenya. Emerg. Infect. Dis. 2009, 15, 482-485. [CrossRef]

21. Pfefferle, S.; Oppong, S.; Drexler, J.F.; Gloza-Rausch, F.; Ipsen, A.; Seebens, A.; Müller, M.A.; Annan, A.; Vallo, P.; Adu-Sarkodie, Y.; et al. Distant relatives of severe acute respiratory syndrome coronavirus and close relatives of human coronavirus 229E in bats, Ghana. Emerg. Infect. Dis. 2009, 15, 1377-1384. [CrossRef] [PubMed]

22. Quan, P.-L.; Firth, C.; Street, C.; Henriquez, J.A.; Petrosov, A.; Tashmukhamedova, A.; Hutchison, S.K.; Egholm, M.; Osinubi, M.O.V.; Niezgoda, M.; et al. Identification of a severe acute respiratory syndrome coronavirus-like virus in a leaf-nosed bat in Nigeria. MBio 2010, 1, e00208-10-e00208-18. [CrossRef] [PubMed]

23. Geldenhuys, M.; Weyer, J.; Nel, L.H.; Markotter, W. Coronaviruses in South African bats. Vector Borne Zoonotic Dis. 2013, 13, 516-519. [CrossRef] [PubMed]

24. Ithete, N.L.; Stoffberg, S.; Corman, V.M.; Cottontail, V.M.; Richards, L.R.; Schoeman, M.C.; Drosten, C.; Drexler, J.F.; Preiser, W. Close relative of human Middle East respiratory syndrome coronavirus in bat, South Africa. Emerg. Infect. Dis. 2013, 19, 1697-1699. [CrossRef] [PubMed]

25. Tao, Y.; Shi, M.; Chommanard, C.; Queen, K.; Zhang, J.; Markotter, W.; Kuzmin, I.V.; Holmes, E.C.; Tong, S. Surveillance of Bat Coronaviruses in Kenya Identifies Relatives of Human Coronaviruses NL63 and 229E and Their Recombination History. J. Virol. 2017, 91, e01953-e01956. [CrossRef] [PubMed]

26. Anthony, S.J.; Gilardi, K.; Menachery, V.D.; Goldstein, T.; Ssebide, B.; Mbabazi, R.; Navarrete-Macias, I.; Liang, E.; Wells, H.; Hicks, A.; et al. Further evidence for bats as the evolutionary source of Middle East respiratory syndrome coronavirus. MBio 2017, 8, 1-13. [CrossRef] [PubMed]

27. Geldenhuys, M.; Mortlock, M.; Weyer, J.; Bezuidt, O.; Seamark, E.; Kearney, T.; Gleasner, C.; Erkkila, T.; Cui, H.; Markotter, W. A metagenomic viral discovery approach identifies potential zoonotic and novel mammalian viruses in Neoromicia bats within South Africa. PLoS ONE 2018, 13, e0194527. [CrossRef]

28. Virtue, E.R.; Marsh, G.A.; Wang, L.-F. Paramyxoviruses infecting humans: the old, the new and the unknown. Future Microbiol. 2009, 4, 537-554. [CrossRef]

29. ICTV Virus Taxonomy: 2018b Release. Available online: https://talk.ictvonline.org/taxonomy/ (accessed on 1 May 2019).

30. Murray, K.; Selleck, P.; Hooper, P.; Hyatt, A.; Gould, A.; Gleeson, L.; Westbury, H.; Hiley, L.; Selvey, L.; Rodwell, B. A morbillivirus that caused fatal disease in horses and humans. Science 1995, 268, 94-97. [CrossRef]

31. Chua, K.B.; Goh, K.J.; Wong, K.T.; Kamarulzaman, A.; Seow, P.; Tan, K.; Ksiazek, T.G.; Zaki, S.R.; Paul, G.; Lam, S.K.; et al. Fatal encephalitis due to Nipah virus among pig farmers in Malaysia. Lancet 1999, 354, 1257-1259. [CrossRef]

32. Albariño, C.G.; Foltzer, M.; Towner, J.S.; Rowe, L.A.; Campbell, S.; Jaramillo, C.M.; Bird, B.H.; Reeder, D.M.; Vodzak, M.E.; Rota, P.; et al. Novel paramyxovirus associated with severe acute febrile disease, South Sudan and Uganda, 2012. Emerg. Infect. Dis. 2014, 20. [CrossRef] [PubMed]

33. Halpin, K.; Young, P.L.; Field, H.E.; Mackenzie, J.S. Isolation of Hendra virus from pteropid bats: A natural reservoir of Hendra virus. J. Gen. Virol. 2000, 81, 1927-1932. [CrossRef] [PubMed]

34. Chua, K.B.; Koh, C.L.; Hooi, P.S.; Wee, K.F.; Khong, J.H.; Chua, B.H.; Chan, Y.P.; Lim, M.E.; Lam, S.K. Isolation of Nipah virus from Malaysian Island flying-foxes. Microbes Infect. 2002, 4, 145-151. [CrossRef] 
35. Baker, K.S.; Todd, S.; Marsh, G.; Wood, J.L.N.; Wang, L.F.; Murcia, P.R.; Cunningham, A.A. Co-circulation of diverse paramyxoviruses in an urban African fruit bat population. J. Gen. Virol. 2012, 93, 850-856. [CrossRef] [PubMed]

36. Mortlock, M.; Kuzmin, I.V.; Weyer, J.; Gilbert, A.T.; Agwanda, B.; Rupprecht, C.E.; Nel, L.H.; Kearney, T.; Malekani, J.M.; Markotter, W. Novel paramyxoviruses in bats from sub-Saharan Africa, 2007-2012. Emerg. Infect. Dis. 2015, 21, 1840-1843. [CrossRef] [PubMed]

37. Mortlock, M.; Dietrich, M.; Weyer, J.; Paweska, J.T.; Markotter, W. Co-circulation and excretion dynamics of diverse rubula-and related viruses in Egyptian rousette bats from South Africa. Viruses 2019, 11, 37. [CrossRef]

38. Van Cakenberghe, V.; Gembu Tungaluna, G.-C.; Musaba Akawa, P.; Seamark, E.; Verheyen, E. The bats of the Congo and of Rwanda and Burundi revisited (Mammalia: Chiroptera). Eur. J. Taxon. 2017, 1-327. [CrossRef]

39. Greenberg, J.A.; Dimenna, M.A.; Hanelt, B.; Hofkin, B.V. Analysis of post-blood meal flight distances in mosquitoes utilizing zoo animal blood meals. J. Vector Ecol. 2012, 37, 83-89. [CrossRef]

40. Folmer, O.; Black, M.; Hoeh, W.; Lutz, R.; Vrijenhoek, R. DNA primers for amplification of mitochondrial cytochrome c oxidase subunit I from diverse metazoan invertebrates. Mol. Mar. Biol. Biotechnol. 1994, 3 , 294-299.

41. Lassen, S.B.; Nielsen, S.A.; Skovgård, H.; Kristensen, M. Molecular identification of bloodmeals from biting midges (Diptera: Ceratopogonidae: Culicoides Latreille) in Denmark. Parasitol. Res. 2011, 108, 823-829. [CrossRef]

42. Tong, S.; Chern, S.W.; Li, Y.; Pallansch, M.A.; Anderson, L.J. Sensitive and Broadly Reactive Reverse Transcription-PCR Assays to Detect Novel Paramyxoviruses. J. Clin. Microbiol. 2008, 46, 2652-2658. [CrossRef] [PubMed]

43. Hall, T. BioEdit: a user-friendly biological sequence alignment editor and analysis program for Windows 95/98/NT. Nucleic Acids Symp. Ser. 1999, 41, 95-98.

44. Darriba, D.; Taboada, G.L.; Doallo, R.; Posada, D. jModelTest 2: more models, new heuristics and highperformance computing. Nat. Methods 2015, 9, 6-9.

45. Drummond, A.J.; Suchard, M.A.; Xie, D.; Rambaut, A. Bayesian Phylogenetics with BEAUti and the BEAST 1.7. Mol. Biol. Evol. 2012, 29, 1969-1973. [CrossRef] [PubMed]

46. Miller, M.A.; Pfeiffer, W.; Schwartz, T. Creating the CIPRES science gateway for inference of large phylogenetic trees. In Proceedings of the Gateway Computing Environments Workshop (GCE), New Orleans, LA, USA, 14 November 2010; pp. 1-8.

47. Rambaut, A.; Drummond, A.J.; Xie, D.; Baele, G.; Suchard, M.A. Posterior Summarization in Bayesian Phylogenetics Using Tracer 1.7. Syst. Biol. 2018, 67, 901-904. [CrossRef] [PubMed]

48. Kumar, S.; Stecher, G.; Li, M.; Knyaz, C.; Tamura, K. MEGA X: Molecular evolutionary genetics analysis across computing platforms. Mol. Biol. Evol. 2018, 35, 1547-1549. [CrossRef] [PubMed]

49. Li, W.; Shi, Z.; Yu, M.; Ren, W.; Smith, C.; Hu, Z.; Zhang, H.; Zhang, J.; Eaton, B.T.; Zhang, S.; et al. Bats are natural reservoirs of SARS-Like coronaviruses. Science 2005, 310, 676-679. [CrossRef] [PubMed]

50. Mélade, J.; Wieseke, N.; Ramasindrazana, B.; Flores, O.; Lagadec, E.; Gomard, Y.; Goodman, S.M.; Dellagi, K.; Pascalis, H. An eco-epidemiological study of Morbilli-related paramyxovirus infection in Madagascar bats reveals host-switching as the dominant macro-evolutionary mechanism. Sci. Rep. 2016, 6, 1-12. [CrossRef]

51. Willoughby, A.R.; Phelps, K.L.; Phelps, K.L.; Predict Consortium; Olival, K.J. A comparative analysis of viral richness and viral sharing in cave-roosting bats. Diversity 2017, 9, 35. [CrossRef]

52. Kurth, A.; Kohl, C.; Brinkmann, A.; Ebinger, A.; Harper, J.A.; Wang, L.-F.; Mühldorfer, K.; Wibbelt, G. Novel paramyxoviruses in free-ranging European bats. PLoS ONE 2012, 7. [CrossRef]

53. Vidgen, M.E.; de Jong, C.; Rose, K.; Hall, J.; Field, H.E.; Smith, C.S. Novel paramyxoviruses in Australian flying-fox populations support host-virus coevolution. J. Gen. Virol. 2015, 96, 1619-1625. [CrossRef] [PubMed]

54. Wilkinson, D.A.; Temmam, S.; Lebarbenchon, C.; Lagadec, E.; Chotte, J.; Guillebaud, J.; Ramasindrazana, B.; Héraud, J.-M.; de Lamballerie, X.; Goodman, S.M.; et al. Identification of novel paramyxoviruses in insectivorous bats of the Southwest Indian Ocean. Virus Res. 2012, 170, 159-163. [CrossRef] [PubMed] 